\title{
A REVIEW STUDY OF ECONOMICS ANALYSIS IN ENGINEERING PROJECTS
}

\author{
Assoc. Professor Dr. Osama Mohammed Elmardi Suleiman \\ Department of Mechanical Engineering \\ Nile Valley University, Atbara, \\ River Nile State, Sudan
}

Abstract — Engineering economics, previously known as engineering economy, is a subset of economics concerned with the use and application of economic principles in the analysis of engineering decisions. As a discipline, it is focused on the branch of economics known as microeconomics in that it studies the behavior of individuals and firms in making decisions regarding the allocation of limited resources. Thus, it focuses on the decision making process, its context and environment. It is pragmatic by nature, integrating economic theory with engineering practice. But, it is also a simplified application of microeconomic theory in that it avoids a number of microeconomic concepts such as price determination, competition and demand/supply. As a discipline though, it is closely related to others such as statistics, mathematics and cost accounting. It draws upon the logical framework of economics but adds to that the analytical power of mathematics and statistics.

Engineers seek solutions to problems, and the economic viability of each potential solution is normally considered along with the technical aspects. Fundamentally, engineering economics involves formulating, estimating, and evaluating the economic outcomes when alternatives to accomplish a defined purpose are available.

The study includes an introduction to the application of economic techniques to the evaluation of design and engineering alternatives, cash flow concepts, interest factors, comparison of alternatives, benefit - cost analysis, and conclusions of the study. One of the objectives of the economic analysis in engineering projects is the good management which consists primarily of making wise decisions; wise decisions in turn involve making a choice between alternatives. Engineering considerations determine the possibility of a project being carried out and point out the alternative ways in which the project could be handled. Economic considerations also largely determine a project's desirability and dictate how it should be carried out.

Keywords - fundamentals, engineering economics analysis, cash flow concepts, interest factors, comparison of alternatives, benefit - cost analysis

\author{
Engineer Nafea Mostafa Muki Nafea \\ Department of Mechanical Engineering \\ Nile Valley University, Atbara, \\ River Nile State, Sudan
}

\section{INTRODUCTION}

Engineering economics is the application of economic techniques to the evaluation of design and engineering alternatives [1] - [5]. The role of engineering economics is to assess the appropriateness of a given project, estimate its value, and justify it from an engineering standpoint.

This study discusses the time value of money and other cashflow concepts, such as compound and continuous interest. It continues with economic practices and techniques used to evaluate and optimize decisions on selection of fire safety strategies. The final section expands on the principles of benefit-cost analysis.

An in-depth treatment of the practices and techniques covered in this compilation is available in the ASTM compilation of standards on building economics [6]. The ASTM compilation also includes case illustrations showing how to apply the practices and techniques to investment decisions.

A broader perspective on the application of engineering economics to fire protection engineering can be found in The Economics of Fire Protection by Ramachandran [7]. This work is intended as a textbook for fire protection engineers and includes material and references that expand on several other studies of this section of the SFPE handbook.

\section{CASH FLOW CONCEPTS}

Cash flow is the stream of monetary (dollar) values, costs (inputs) and benefits (outputs) resulting from a project investment.

\section{A. Time Value of Money}

The following are reasons why $\$ 1000$ today is "worth" more than $\$ 1000$ one year from today:

1. Inflation.

2. Risk.

3. Cost of money.

Of these, the cost of money is the most predictable, and, hence, it is the essential component of economic analysis. Cost of money is represented by (1) money paid for the use of borrowed money, or (2) return on investment. Cost of money is determined by an interest rate.

Time value of money is defined as the time-dependent value of money stemming both from changes in the purchasing 


\section{International Journal of Engineering Applied Sciences and Technology, 2021 \\ Vol. 6, Issue 4, ISSN No. 2455-2143, Pages 1-9 \\ Published Online August 2021 in IJEAST (http://www.ijeast.com)}

power of money (inflation or deflation) and from the real earning potential of alternative investments over time.

\section{B. Cash Flow Diagrams}

It is difficult to solve a problem if you cannot see it. The easiest way to approach problems in economic analysis is to draw a picture. The picture should show three things:

1. A time interval divided into an appropriate number of equal periods.

2. All cash outflows (deposits, expenditures, etc.) in each period.

3. All cash inflows (withdrawals, income, etc.) for each period.

Unless otherwise indicated, all such cash flows are considered to occur at the end of their respective periods.

Fig. 1 is a cash-flow diagram showing an outflow or disbursement of $\$ 1000$ at the beginning of year 1 and an inflow or return of $\$ 2000$ at the end of year 5 .

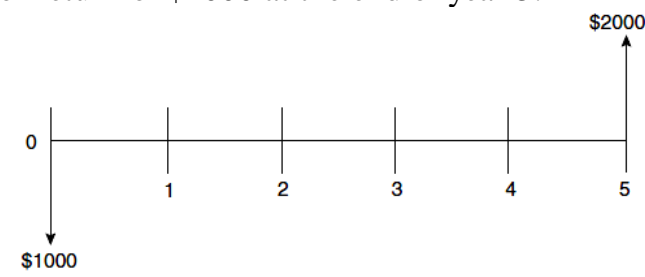

Fig. 1. Cash-Flow Diagram

\section{Notation}

To simplify the subject of economic analysis, symbols are introduced to represent types of cash flows and interest factors. The symbols used in this study conform to ANSI Z94; [8]. However, not all practitioners follow this standard convention, and care must be taken to avoid confusion when reading the literature. The following symbols will be used here:

$\mathrm{P}=$ Present sum of money $(\$)$

$\mathrm{F}=$ Future sum of money $(\$)$

$\mathrm{N}=$ Number of interest periods

$i=$ Interest rate per period (\%)

\section{Interest Calculations}

Interest is the money paid for the use of borrowed money or the return on invested capital. The economic cost of construction, installation, ownership, or operation can be estimated correctly only by including a factor for the economic cost of money.

\section{D.1 Simple Interest:}

To illustrate the basic concepts of interest an additional notation will be used:

$\mathrm{F}(\mathrm{N})=$ Future sum of money after $\mathrm{N}$ periods

Then, for simple interest,

$F(1)=P+(P)(i)=P(1+i)$

And
$F(N)=P+(N)(P)(i)=P(1+N i)$

For example: $\$ 100$ at 10 percent per year for 5 yrs. yields $F(5)=100[1+(5)(0.1)]$

$=100(1.5)$

$=\$ 150$

However, interest is almost universally compounded to include interest on the interest.

\section{D.2 Compound Interest:}

$F(1)=P+(P)(i)=P(1+i)$

is the same as simple interest,

$F(2)=F(1)+F(1)(i)$

Interest is applied to the new sum:

$=(F)(1)(1+i)=P(1+i)^{2}$

$F(3)=F(2)(1+i)=P(1+i)^{3}$

And by mathematical induction,

$F(N)=P(1+i)^{N}$

Example (1):

$\$ 100$ at 10 percent per year for 5 yrs. yields

$F(5)=100(1+0.1)^{5}$

$=100(1.1)^{5}$

$=100(1.61051)$

$=\$ 161.05$

Which is over 7 percent greater than with simple interest.

Example (2):

In 1626 Willem Verhulst bought Manhattan Island from the Canarsie Indians for 60 florins (\$24) worth of merchandise (a price of about 0.5 cents per hectare [ 0.2 cents per acre]). At an average interest rate of 6 percent, what is the present value (2001) of the Canarsies' \$24?

$F=P(1+i)^{N}$

$=C \$ 24(1+0.06)^{375}$

$=\$ 7.4 \times 10^{10}$

Seventy four billion dollars is a reasonable approximation of the present land value of the island of Manhattan

\section{INTEREST FACTORS}

Interest factors are multiplicative numbers calculated from interest formulas for given interest rates and periods. They are used to convert cash flows occurring at different times to a common time. The functional formats used to represent these factors are taken from ANSI Z94.

\section{A. Compound Amount Factor}

In the formula for finding the future value of a sum of money with compound interest, the mathematical expression $(1+i)^{N}$ is referred to as the compound amount factor, 


\section{International Journal of Engineering Applied Sciences and Technology, 2021 \\ Vol. 6, Issue 4, ISSN No. 2455-2143, Pages 1-9 \\ Published Online August 2021 in IJEAST (http://www.ijeast.com)}

represented by the functional format $(\mathrm{F} / \mathrm{P}, \mathrm{i}, \mathrm{N})$. Thus, $F=P(F / P, i, N)$

\section{B. Interest tables:}

Values of the compound amount, present worth, and other factors that will be discussed shortly, are tabulated for a variety of interest rates and number of periods in most texts on engineering economy. Although calculators and computers have greatly reduced the need for such tables, they are often still useful for interpolations.

\section{Present Worth}

Present worth is the value found by discounting future cash flows to the present or base time.

\section{C.1 Discounting:}

The inverse of compounding is determining a present amount which will yield a specified future sum. This process is referred to as discounting. The equation for discounting is found readily by using the compounding equation to solve for $\mathrm{P}$ in terms of $\mathrm{F}$ :

$P=F(1+i)^{-N}$

Example (3):

What present sum will yield $\$ 1000$ in 5 yrs. at 10 percent?

$P=1000(1.1)^{-5}$

$=1000(0.62092)$

$=\$ 620.92$

This result means that $\$ 620.92$ "deposited" today at 10 percent compounded annually will yield $\$ 1000$ in 5 yrs.

\section{C.2 Present Worth Factor}

In the discounting equation, the expression $(1+i)^{-N}$ is called the present worth factor and is represented by the symbol $(\mathrm{P} / \mathrm{F}, \mathrm{i}, \mathrm{N})$. Thus, for the present worth of a future sum at i percent interest for $\mathrm{N}$ periods,

$P=F(P / F, i, N)$

Note that the present worth factor is the reciprocal of the compound amount factor. Also note that

$$
(P / F, i, N)=\frac{1}{(F / P, i, N)}
$$

\section{Example (4):}

What interest rate is required to triple $\$ 1000$ in 10 years?

$P=\frac{F}{3}(P / F, i, 10)$

Therefore,

$(P / F, i, 10)=\frac{1}{3}$

From interest tables,

$(P / F, 10 \%, 10)=0.3855$

And
$(P / F, 12 \%, 10)=0.3220$

By linear interpolation,

$$
i=11.6 \%
$$

\section{Interest Periods}

Normally, but not always, the interest period is taken as $1 \mathrm{yr}$. There may be sub periods of quarters, months, weeks, and so forth.

\section{D.1 Nominal versus Effective Interest}

It is generally assumed that interest is compounded annually. However, interest may be compounded more frequently. When this occurs, there is a nominal interest or annual percentage rate and an effective interest, which is the figure used in calculations. For example, a savings bank may offer 5 percent interest compounded quarterly, which is not the same as 5 percent per year. A nominal rate of 5 percent compounded quarterly is the same as 1.25 percent every three months or an effective rate of 5.1 percent per year. If

$$
r=\text { Nominal interest rate, }
$$

And

$$
M=\text { Number of sub periods per year }
$$

Then the effective interest rate is

$i=\left(1+\frac{r}{M}\right)^{M}-1$

Example (5):

Credit cards usually charge interest at a rate of 1.5 percent per month. This amount is a nominal rate of 18 percent. What is the effective rate?

$$
\begin{aligned}
& i=(1+0.015)^{12}-1 \\
& =1.1956-1 \\
& =19.56 \%
\end{aligned}
$$

\section{D.2 Continuous Interest}

A special case of effective interest occurs when the number of periods per year is infinite. This represents a situation of continuous interest, also referred to as continuous compounding. Formulas for continuous interest can be derived by examining limits as $\mathrm{M}$ approaches infinity. Continuous interest is compared to monthly interest in Table 1.

Table -1 Continuous Interest (\%)

\begin{tabular}{ccc}
\hline & \multicolumn{2}{c}{ Effective } \\
\cline { 2 - 3 } Nominal \% & Monthly & Continuous \\
\hline 5 & 5.1 & 5.1 \\
10 & 10.5 & 10.5 \\
15 & 16.1 & 16.2 \\
20 & 21.9 & 22.1 \\
\hline
\end{tabular}




\section{International Journal of Engineering Applied Sciences and Technology, 2021 \\ Vol. 6, Issue 4, ISSN No. 2455-2143, Pages 1-9 \\ Published Online August 2021 in IJEAST (http://www.ijeast.com)}

Example (6):

Compare the future amounts obtained under various compounding periods at a nominal interest rate of 12 percent for 5 yrs., if $\mathrm{P}=\$ 10,000$. (See Table 2).

Table -2 Example of Continuous Interest $\mathrm{N}=5$ yrs., $\mathrm{r}=12 \%$

\begin{tabular}{lrcrcc}
\hline Compounding & \multicolumn{1}{c}{$M$} & \multicolumn{1}{c}{$\boldsymbol{c}$ NM } & FIP & $F$ \\
\hline Annual & 1 & 12.000 & 5 & 1.76234 & $17,623.40$ \\
Semi-annual & 2 & 12.360 & 10 & 1.79085 & $17,908.50$ \\
Quarterly & 4 & 12.551 & 20 & 1.80611 & $18,061.10$ \\
Monthly & 12 & 12.683 & 60 & 1.81670 & $18,167.00$ \\
Weekly & 52 & 12.734 & 260 & 1.820860 & $18,208.60$ \\
Daily & 365 & 12.747 & 1825 & 1.821938 & $18,219.38$ \\
Hourly & 8760 & 12.749 & 43,800 & 1.822061 & $18,220.61$ \\
Instantaneously & $\infty$ & 12.750 & $\infty$ & $1.822119^{a}$ & $18,221.19$ \\
\hline
\end{tabular}

aF/P (instantaneous) $=e^{N i}=e^{5(0.12)}=e^{0.6}$

\section{E. Series Payments}

Life would be simpler if all financial transactions were in single lump-sum payments, now or at some time in the future. However, most situations involve a series of regular payments, for example, car loans and mortgages.

\section{E.1 Series Compound Amount Factor}

Given a series of regular payments, what will they be worth at some future time?

Let, $\mathrm{A}=$ the amount of a regular end-of-period payment

Then, note that each payment, A, is compounded for a different period of time. The first payment will be compounded for $\mathrm{N}-1$ periods (yrs.):

$F=A(1+i)^{N-1}$

And the second payment for $\mathrm{N}-2$ periods:

$F=A(1+i)^{N-2}$

And so forth. Thus, the total future value is

$F=A(1+i)^{N-1}+A(1+i)^{N-2}+\cdots+A(1+i)+A$

$\mathrm{Or}$

$F=\frac{A\left[(1+i)^{N}-1\right]}{i}$

The interest expression in this equation is known as the series compound amount factor, (F/A, i, N), thus

$F=P(F / P, i, N)$

\section{E.2 Sinking Fund Factor}

The process corresponding to the inverse of series compounding is referred to as a sinking fund; that is, what size regular series payments are necessary to acquire a given future amount?

Solving the series compound amount equation for A,

$A=F\left\{\frac{i}{\left[(1+i)^{N}-1\right]}\right\}$

Or, using the symbol $(\mathrm{A} / \mathrm{F}, \mathrm{i}, \mathrm{N})$ for the sinking fund factor

$A=F(A / F, i, N)$
Here, note that the sinking fund factor is the reciprocal of the series compound amount factor, that is, $(A / F, i, N)=1 /(F / A, i, N)$.

\section{E.3 Capital Recovery Factor}

It is also important to be able to relate regular periodic payments to their present worth; for example, what monthly installments will pay for a $\$ 10,000$ car in 3 yrs. at 15 percent? Substituting the compounding equation $F=P(F / P, i, N)$ in the sinking fund equation, $A=F(A / F, i, N)$, yields $A=P(F / P, i, N)(A / F, i, N)$

And, substituting the corresponding interest factors gives

$A=P \frac{\left[i(1+i)^{N}\right]}{\left[(1+i)^{N}-1\right]}$

In this equation, the interest expression is known as the capital recovery factor, since the equation defines a regular income necessary to recover a capital investment. The symbolic equation is

$$
A=P(A / P, i, N)
$$

\section{E.4 Series Present Worth Factor}

As with the other factors, there is a corresponding inverse to the capital recovery factor. The series present worth factor is found by solving the capital recovery equation for $\mathrm{P}$.

$P=A \frac{\left[(1+i)^{N}-1\right]}{\left[i(1+i)^{N}\right]}$

Or, symbolically

$P=A(P / A, i, N)$

\section{F. Other Interest Calculation Concepts}

Additional concepts involved in interest calculations include continuous cash flow, capitalized costs, beginning of period payments, and gradients.

\section{F.1 Continuous Cash Flow}

Perhaps the most useful function of continuous interest is its application to situation where the flow of money is of a continuous nature. Continuous cash flow is representative for: 1. A series of regular payments for which the interval between payments is very short.

2. A disbursement at some unknown time (which is then considered to be spread out over the economic period).

Factors for calculating present or future worth of a series of annual amounts, representing the total of a continuous cash flow throughout the year, may be derived by integrating corresponding continuous interest factors over the number of years the flow is maintained.

Continuous cash flow is an appropriate way to handle economic evaluations of risk, for example, the present value of an annual expected loss [9]. 


\section{International Journal of Engineering Applied Sciences and Technology, 2021 \\ Vol. 6, Issue 4, ISSN No. 2455-2143, Pages 1-9 \\ Published Online August 2021 in IJEAST (http://www.ijeast.com)}

\section{F.2 Capitalized Costs}

Sometimes there are considerations, such as some public works projects, which are considered to last indefinitely and thereby provide perpetual service. For example, how much should a community be willing to invest in a reservoir which will reduce fire insurance costs by some annual amount, A? Taking the limit of the series present worth factor as the number of periods goes to infinity gives the reciprocal of the interest rate. Thus, capitalized costs are just the annual amount divided by the interest rate. When expressed as an amount required produce a fixed yield in perpetuity, it is sometimes referred to as an annuity.

\section{F.3 Beginning of Period for Payments}

Most returns on investment (cash inflows) occur at the end of the period during which they accrued. For example, a bank computes and pays interest at the end of the interest period. Accordingly, interest tables are computed for end-of-year payments. For example, the values of the capital recovery factor $(\mathrm{A} / \mathrm{P}, \mathrm{i}, \mathrm{N})$ assume that the regular payments, $\mathrm{A}$, occur at the end of each period.

On the other hand, most disbursements (cash outflows) occur at the beginning of the period (e.g., insurance premiums). When dealing with beginning-of-period payments, it is necessary to make adjustments. One method of adjustment for beginning-of-period payments is to calculate a separate set of factors. Another way is to logically interpret the effect of beginning-of-period payments for a particular problem, for example, treating the first payment as a present value. The important thing is to recognize that such variations can affect economic analysis.

\section{F.4 Cash Flow Gradients}

It occasionally becomes necessary to treat the case of a cash flow which regularly increases or decreases at each period. Such patterned changes in cash flow are called gradients. They may be a constant amount (linear or arithmetic progression), or they may be a constant percentage (exponential or geometric progression).

\section{COMPARISON OF ALTERNATIVES}

Most decisions are based on economic criteria. Investments are unattractive; unless it seems likely they will be recovered with interest. Economic decisions can be divided into two classes:

1. Income-expansion-that is, the objective of capitalism.

2. Cost-reduction-the basis of profitability.

Fire protection engineering economic analysis is primarily concerned with cost-reduction decisions, finding the least expensive way to fulfill certain requirements, or minimizing the sum of expected fire losses plus investment in fire protection.
There are four common methods of comparing alternative investments: (1) present worth, (2) annual cost, (3) rate of return, and (4) benefit-cost analysis. Each of these is dependent on a selected interest rate or discount rate to adjust cash flows at different points in time [10].

\section{A. Discount Rate}

The term discount rate is often used for the interest rate when comparing alternative projects or strategies.

\section{A.1 Selection of Discount Rate}

If costs and benefits accrue equally over the life of a project or strategy, the selection of discount rate will have little impact on the estimated benefit-cost ratios. However, most benefits and costs occur at different times over the project life cycle. Thus, costs of constructing a fire-resistive building will be incurred early in contrast to benefits, which will accrue over the life of the building. The discount rate then has a significant impact on measures such as benefit-cost ratios, since the higher the discount rate, the lower the present value of future benefits.

In view of the uncertainty concerning appropriate discount rate, analysts frequently use a range of discount rates. This procedure indicates the sensitivity of the analysis to variations in the discount rate. In some instances, project rankings based on present values may be affected by the discount rate as shown in Fig. 2 below [11] and [12].

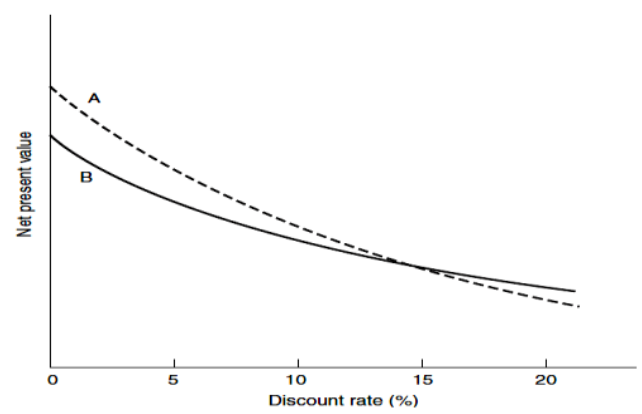

Fig. 2. Impact of Discount Rate on Project Selection

Project A is preferred to project B for discount rates below 15 percent, while the converse is true for discount rates greater than 15 percent. In this instance, the decision to adopt project $\mathrm{A}$ in preference to project $\mathrm{B}$ will reflect the belief that the appropriate discount rate is less than or equal to 15 percent.

A comparison of benefits and costs may also be used to determine the payback period for a particular project or strategy. However, it is important to discount future costs or benefits in such analyses. For example, an analysis of the Beverly Hills Supper Club fire compared annual savings from a reduction in insurance premiums to the costs of sprinkler installation. Annual savings were estimated at $\$ 11,000$, while costs of sprinkler installation ranged from $\$ 42,000$ to $\$ 68,000$. It was concluded that the installation would have been paid back in four to seven years (depending on the cost of the 


\section{International Journal of Engineering Applied Sciences and Technology, 2021 \\ Vol. 6, Issue 4, ISSN No. 2455-2143, Pages 1-9 \\ Published Online August 2021 in IJEAST (http://www.ijeast.com)}

sprinklers). However, this analysis did not discount future benefits, so that $\$ 11,000$ received at the end of four years was deemed equivalent to $\$ 11,000$ received in the first year. Once future benefits are discounted, the payback period ranges from five to eleven years with a discount rate of 10 percent.

\section{A.2 Inflation and the Discount Rate}

Provision for inflation may be made in two ways: (1) estimate all future costs and benefits in constant prices, and use a discount rate which represents the opportunity cost of capital in the absence of inflation; or (2) estimate all future benefits and costs in current or inflated prices, and use a discount rate which includes an allowance for inflation. The discount rate in the first instance may be considered the real discount rate, while the discount rate in the second instance is the nominal discount rate. The use of current or inflated prices with the real discount rate, or constant prices with the nominal discount rate, will result in serious distortions in economic analysis.

\section{B. Present Worth}

In a present worth comparison of alternatives, the costs associated with each alternative investment are all converted to a present sum of money, and the least of these values represents the best alternative. Annual costs, future payments, and gradients must be brought to the present. Converting all cash flows to present worth is often referred to as discounting.

\section{Example (7)}

Two alternate plans are available for increasing the capacity of existing water transmission lines between an unlimited source and a reservoir. The unlimited source is at a higher elevation than the reservoir. Plan A calls for the construction of a parallel pipeline and for flow by gravity. Plan B specifies construction of a booster pumping station. Estimated cost data for the two plans are as follows:

\begin{tabular}{lcc}
\hline & $\begin{array}{c}\text { Plan A } \\
\text { Pipeline }\end{array}$ & $\begin{array}{c}\text { Plan B } \\
\text { Pumping Station }\end{array}$ \\
\hline $\begin{array}{l}\text { Construction cost } \\
\text { Life }\end{array}$ & $\begin{array}{c}\$ 1,000,000 \\
40 \text { years }\end{array}$ & $\begin{array}{c}\$ 200,000 \\
40 \text { years (structure) }\end{array}$ \\
$\begin{array}{l}\text { Cost of replacing } \\
\text { equipment at the } \\
\text { end of 20 yr }\end{array}$ & & 20 years (equipment) \\
Operating costs & 0 & $\$ 75,000$ \\
\hline
\end{tabular}

If money is worth 12 percent, which plan is more economical? (Assume annual compounding, zero salvage value, and all other costs equal for both plans.)

Present worth $(\mathrm{Plan} A)=\mathrm{P}+\mathrm{A}(\mathrm{P} / \mathrm{A}, 12 \%, 40)$

$=\$ 1,000,000=\$ 1000(8.24378)$

$=\$ 1,008,244$

Present worth $(\mathrm{Plan} \mathrm{B})=\mathrm{P}=\mathrm{A}(\mathrm{P} / \mathrm{A}, 12 \%, 40)+\mathrm{F}(\mathrm{P} / \mathrm{F}, 12 \%$, 20)

$=\$ 200,000=\$ 50,000(8.24378)+\$ 75,000(0.10367)$

$=\$ 619,964$
Thus, plan B is the least-cost alternative.

A significant limitation of present worth analysis is that it cannot be used to compare alternatives with unequal economic lives. That is, a ten-year plan and a twenty-year plan should not be compared by discounting their costs to a present worth. A better method of comparison is annual cost.

\section{Annual Cost}

To compare alternatives by annual cost, all cash flows are changed to a series of uniform payments. Current expenditures, future costs or receipts, and gradients must be converted to annual costs. If a lump-sum cash flow occurs at some time other than the beginning or end of the economic life, it must be converted in a two-step process: first moving it to the present and then spreading it uniformly over the life of the project.

Alternatives with unequal economic lives may be compared by assuming replacement in kind at the end of the shorter life, thus maintaining the same level of uniform payment.

\section{Example (8)}

Compare the value of a partial or full sprinkler system purchased at 10 percent interest.

\begin{tabular}{lccc}
\hline & System Cost & $\begin{array}{c}\text { Insurance } \\
\text { Premium }\end{array}$ & Life \\
\hline Partial system & $\$ 8000$ & $\$ 1000$ & $15 \mathrm{yr}$ \\
Full system & $\$ 15,000$ & $\$ 250$ & $20 \mathrm{yr}$ \\
\hline
\end{tabular}

Annual cost $($ partial system $)=\mathrm{A}+\mathrm{P}(\mathrm{A} / \mathrm{P}, 10 \%, 15)$

$=\$ 1000+\$ 8000(0.13147)$

$=\$ 2051.75$

Annual cost (full system) $\quad=\mathrm{A}+\mathrm{P}(\mathrm{A} / \mathrm{P}, 10 \%, 20)$

$=\$ 250+\$ 15,000(0.11746)$

$=\$ 2011.90$

The full system is slightly more economically desirable. When costs are this comparable, it is especially important to consider other relevant decision criteria, for example, uninsured losses.

\section{Rate of Return}

Rate of return is, by definition, the interest rate at which the present worth of the net cash flow is zero. Computationally, this method is the most complex method of comparison. If more than one interest factor is involved, the solution is by trial and error. Microcomputer programs are most useful with this method.

The calculated interest rate may be compared to a discount rate identified as the "minimum attractive rate of return" or to the interest rate yielded by alternatives. Rate-of-return analysis is useful when the selection of a number of projects is to be undertaken within a fixed or limited capital budget. 


\section{International Journal of Engineering Applied Sciences and Technology, 2021 \\ Vol. 6, Issue 4, ISSN No. 2455-2143, Pages 1-9 \\ Published Online August 2021 in IJEAST (http://www.ijeast.com)}

\section{Example (9)}

An industrial firefighting truck costs $\$ 100,000$. Savings in insurance premiums and uninsured losses from the acquisition and operation of this equipment is estimated at $\$ 60,000 / \mathrm{yr}$. Salvage value of the apparatus after 5 yrs. is expected to be $\$ 20,000$. A full-time driver during operating hours will accrue an added cost of $\$ 10,000 / y r$. What would the rate of return be on this investment?

@ 40\% present worth

$=\mathrm{P}+\mathrm{F}(\mathrm{P} / \mathrm{F}, 40 \%, 5)+\mathrm{A}(\mathrm{P} / \mathrm{A}, 40 \%, 5)$

$=-\$ 100,000+\$ 20,000(0.18593)+(\$ 60,000-10,000)(2.0352)$

$=-\$ 5,478.60$

@ 50\% present worth

$=\mathrm{P}+\mathrm{F}(\mathrm{P} / \mathrm{F}, 50 \%, 5)+\mathrm{A}(\mathrm{P} / \mathrm{A}, 50 \%, 5)$

$=-\$ 100,000+\$ 20,000(0.13169)+(\$ 60,000-\$ 10,000)$

(1.7366)

$=-\$ 10,536.40$

By linear interpolation, the rate of return is 43 percent.

\section{BENEFIT - COST ANALYSIS}

Benefit-cost analysis, also referred to as cost-benefit analysis, is a method of comparison in which the consequences of an investment are evaluated in monetary terms and divided into the separate categories of benefits and costs. The amounts are then converted to annual equivalents or present worth for comparison.

The important steps of a benefit-cost analysis are:

1. Identification of relevant benefits and costs.

2. Measurement of these benefits and costs.

3. Selection of best alternative.

4. Treatment of uncertainty.

\section{A. Identification of Relevant Benefits and Costs}

The identification of benefits and costs depends on the particular project under consideration. Thus, in the case of fire prevention or control activities, the benefits are based on fire losses prior to such activities. Fire losses may be classified as direct or indirect. Direct economic losses are property and contents losses. Indirect losses include such things as the costs of injuries and deaths, costs incurred by business or industry due to business interruption, losses to the community from interruption of services, loss of payroll or taxes, loss of market share, and loss of reputation. The direct costs of fire protection activities include the costs of constructing fire-resistive buildings, installation costs of fire protection systems, and the costs of operating fire departments. Indirect costs are more difficult to measure. They include items such as the constraints on choice due to fire protection requirements by state and local agencies.

A major factor in the identification of relevant benefits and costs pertains to the decision unit involved. Thus, if the decision maker is a property owner, the relevant benefits from fire protection are likely to be the reduction in fire insurance premiums and fire damage or business interruption losses not covered by insurance. In the case of a municipality, relevant benefits are the protection of members of the community, avoidance of tax and payroll losses, and costs associated with assisting fire victims. Potential benefits, in these instances, are considerably greater than those faced by a property owner. However, the community may ignore some external effects of fire incidents. For example, the 1954 automobile transmission plant fire in Livonia, Michigan, affected the automobile industry in Detroit and various automobile dealers throughout the United States. However, there was little incentive for the community to consider such potential losses in their evaluation of fire strategies, since they would pertain to persons outside the community. It might be concluded, therefore, that the more comprehensive the decision unit, the more likely the inclusion of all relevant costs and benefits, in particular, social costs and benefits.

\section{B. Measurement of Benefits and Costs}

Direct losses are measured or estimated statistically or by a priori judgment. Actuarial fire-loss data collected nationally or for a particular industry may be used, providing it is adequately specific and the collection mechanism is reliable. More often, an experienced judgment of potential losses is made, sometimes referred to as the maximum probable loss (MPL).

Indirect losses, if considered, are much more difficult to appraise. A percentage or multiple of direct losses is sometimes used. However, when indirect loss is an important decision parameter, a great deal of research into monetary evaluation may be necessary. Procedures for valuing a human life and other indirect losses are discussed in Ramachandran [7].

In the measurement of benefits, it is appropriate to adjust for utility or disutility which may be associated with a fire loss.

Costs may be divided into two major categories: (1) costs of private fire protection services, and (2) costs of public fire protection services. In either case, cost estimate will reflect the opportunity cost of providing the service. For example, the cost of building a fire-resistive structure is the production foregone due to the diversion of labor and resources to make such a structure. Similarly, the cost of a fire department is the loss of other community services which might have been provided with the resources allocated to the fire department.

\section{Selection of Best Alternative}

There are two considerations in determining benefit cost criteria. The first pertains to project acceptability, while the second pertains to project selection.

Project acceptability may be based on benefit-cost difference or benefit-cost ratio. Benefit-cost ratio is a measure of project worth in which the monetary equivalent benefits are divided by the monetary equivalent costs. The first criterion requires that the value of benefits less costs be greater than zero, while the second criterion requires that the benefit-cost ratio be greater than one. 


\section{International Journal of Engineering Applied Sciences and Technology, 2021 \\ Vol. 6, Issue 4, ISSN No. 2455-2143, Pages 1-9 \\ Published Online August 2021 in IJEAST (http://www.ijeast.com)}

The issue is more complicated in the case of project selection, since several alternatives are involved. It is no longer a question of determining the acceptability of a single project, but rather selecting from among alternative projects. Consideration should be given to changes in costs and benefits as various strategies are considered. Project selection decisions are illustrated in Fig. 3. The degree of fire protection is given on the horizontal axis, while the marginal costs and benefits associated with various levels of fire safety are given on the vertical axis. As the diagram indicates, marginal costs are low initially and then increase. Less information is available concerning the marginal benefit curve, and it may, in fact, be horizontal. The economically optimum level of fire protection is given by the intersection of the marginal cost and marginal benefit curves. Beyond this point, benefits from increasing fire protection are exceeded by the costs of providing the additional safety.

A numerical example is given in Table 3. There are five possible strategies or programs possible. The first strategy, A, represents the initial situation, while the remaining four strategies represent various fire loss reduction activities, each with various costs. Strategies are arranged in ascending order of costs. Fire losses under each of the five strategies are given in the second row, while the sum of fire losses and fire reduction costs for each strategy is given in the third row. The sum of fire losses and fire reduction costs of each strategy is equivalent to the life-cycle cost of that strategy. Life-cycle cost analysis is an alternative to benefit-cost analysis when the outcomes of the investment decision are cost savings rather than benefits per se. Additional information on life-cycle cost analysis is found in Fuller and Petersen [13].

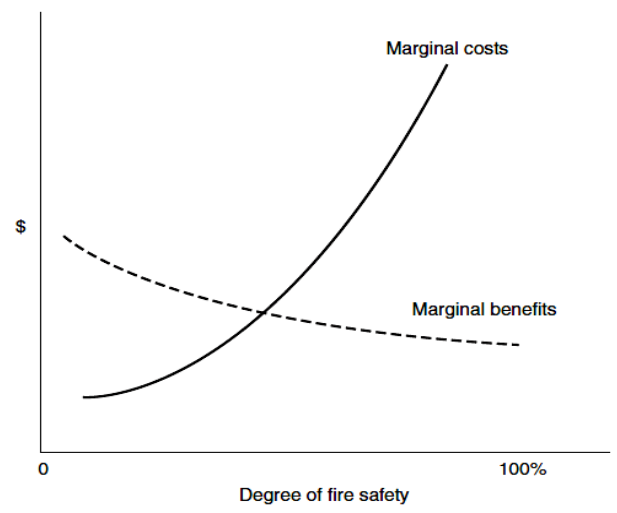

Fig. 3. Project Selection

Table -3 Use of Benefit-Cost Analyses in Strategy Selection

\begin{tabular}{lrrccr}
\hline & \multicolumn{5}{c}{ Strategy } \\
\cline { 2 - 6 } Category & A & B & C & D & E \\
\hline Fire reduction costs & 0 & 10 & 25 & 45 & 70 \\
Fire losses & 100 & 70 & 50 & 40 & 35 \\
$\begin{array}{l}\text { Sum of fire reduction } \\
\quad \text { costs and fire losses }\end{array}$ & 100 & 80 & 75 & 85 & 105 \\
\hline Marginal benefits & 0 & 30 & 20 & 10 & 5 \\
$\quad$ Marginal costs & 0 & 10 & 15 & 20 & 25 \\
$\quad$ Marginal benefits minus & & & & & \\
$\quad$ marginal costs & 0 & 20 & 5 & -10 & -20 \\
$\quad$ Marginal benefit-cost ratio & - & 3.0 & 1.33 & 0.5 & 0.2 \\
\hline
\end{tabular}

Data in the first two rows may then be used to determine the marginal costs or marginal benefits from the replacement of one strategy by another. Thus, strategy B has a fire loss of $\$ 70$ compared to $\$ 100$ for strategy $\mathrm{A}$, so the marginal benefit is $\$ 30$. Similarly, the marginal benefit from strategy $\mathrm{C}$ is the reduction in fire losses from $\mathrm{B}$ to $\mathrm{C}$ or $\$ 20$. The associated marginal cost of strategy $C$ is $\$ 15$. Declining marginal benefits and rising marginal costs result in the selection of strategy $\mathrm{C}$ as the optimum strategy. At this point, the difference between marginal benefits and marginal costs is still positive.

Marginal benefit-cost ratios are given in the last row. It is worth noting that, while the highest marginal benefit cost ratio is reached at activity level $\mathrm{B}$ (as is the highest marginal benefit-cost difference), project $\mathrm{C}$ is still optimum, since it yields an additional net benefit of $\$ 5$. This finding is reinforced by examining changes in the sum of fire losses and fire reduction costs (i.e., life-cycle costs). Total cost plus loss first declines, reaching a minimum at point $\mathrm{C}$, and then increases. This pattern is not surprising, since as long as marginal benefits exceed marginal costs, total losses should decrease. Thus, the two criteria-equating marginal costs and benefits, and minimizing the sum of fire losses and fire reduction costs-yield identical outcomes.

\section{Treatment of Uncertainty}

A final issue concerns the treatment of uncertainty. One method for explicitly introducing risk considerations is to treat benefits and costs as random variables which may be described by probability distributions. For example, an estimate of fire losses might consider the following events: no fire, minor fire, intermediate fire, and major fire. Each event has a probability of occurrence and an associated damage loss. The total expected loss (EL) is given by

$E L=\sum_{i=0}^{3} p_{i} D_{i}$

Where,

$p_{0}=$ probability of no fire

$p_{1}=$ probability of a minor fire

$p_{2}=$ probability of an intermediate fire

$p_{3}=$ probability of a major fire

$D_{n}=$ associated damage loss, $\mathrm{n}=0,1,2,3$ 


\section{International Journal of Engineering Applied Sciences and Technology, 2021 \\ Vol. 6, Issue 4, ISSN No. 2455-2143, Pages 1-9 \\ Published Online August 2021 in IJEAST (http://www.ijeast.com)}

Expected losses may be computed for different fire protection strategies. Thus, a fire protection strategy that costs $\mathrm{C}_{3}$ and reduces damage losses of a major fire from $D_{3}$

to $D_{3}^{s}$ will result in an expected loss

$E L=p_{0} D_{0}+p_{1} D_{1}+p_{2} D_{2}+p_{3} D_{3}^{\prime}+C 3$

Similarly, a fire control strategy that costs $C_{2}$ and reduces the probability of an intermediate fire from $p_{2}$ to $p_{2}^{t}$ has an expected loss

$E L=p_{0} D_{0}+p_{1} D_{1}+p_{2}^{J} D_{2}+p_{3} D_{3}+C_{2}$

A comparison of expected losses from alternative strategies may then be used to determine the optimal strategy.

Use of expected value has a limitation in that only the average value of the probability distribution is considered. Discussion of other procedures for evaluating uncertain outcomes is given by Anderson and Settle [14].

\section{CONCLUSIONS}

Most engineers can recall the "scientific method", which involves five distinct phases: observation, problem definition, formulation of hypothesis, experimentation, and verification. A similar sequence of ten clearly defined steps is involved in carrying out the economic analysis of a project: understand the problem, define the energy integrated system, interpret the data, devise the alternatives, evaluate the alternatives, identify the best alternative, suggest the best alternative to the director of the project and get the feedback information, monitor the results, determine that the energy integrated system could be disseminated, including where, and under what conditions.

In this study, the projects are considered in an engineering sense. The ultimate objective of the economic analysis is to provide a decision-making tool which can be used not only for the pilot project also for demonstration purposes.

\section{REFERENCES}

[1] M. Watts Jr, John \& E. Chapman, Robert. (2016). Engineering Economics, 10.1007/978-1-4939-2565-0_81.

[2] M. Elmardi Osama, (2018). Engineering Economics Lecture Notes, www.ektab.com, Jordan.

[3] M. Elmardi Osama, (2018). Engineering Economic Analysis, www.ektab.com, Jordan.

[4] ASTM E833, (1999). Definitions of Terms Relating to Building Economics, American Society for Testing and Materials, West Conshohocken, PA.

[5] Dr. Osama Mohammed Elmardi Suleiman Khayal \& Mohammed Idris Osman, TECHNICAL AND ECONOMIC FEASIBILITY STUDY OF ESTABLISHING ETHANOL FUEL PLANT IN KENANA SUGAR COMPANY, GLOBAL
PUBLICATION HOUSE| International Journal of Applied Science|, Volume 02 || Issue 10|| Oct. 2019.

[6] ASTM Standards on Building Economics, 4th ed., (1999) American Society for Testing and Materials, West Conshohocken, PA.

[7] G. Ramachandran, (1998). The Economics of Fire Protection, E \& FN Spon, London (1998).

[8] American National Standards Institute Standard Z94.01982, (1983). Industrial Engineering Terminology, Chapter 5, Engineering Economy, Industrial Engineering and Management Press, Atlanta, GA.

[9] Ayyub, Bilal M., (2014). Risk Analysis in Engineering and Economics, Second Edition. Boca Raton, Fla: Chapman and Hall/CRC. Frederick, Shane, George Loewenstein, and Ted O'Donoghue, (2002). Time Discounting and Time Preference: A Critical Review. Journal of Economic Literature 40 (2): 351-401.

[10] Frederick, Shane, George Loewenstein, and Ted O'Donoghue, (2002). Time Discounting and Time Preference: A Critical Review. Journal of Economic Literature 40 (2): 351-401.

[11] Hadar, Josef and William Russell, (1969). Rules for Ordering Uncertain Prospects, The American Economic Review Vol. 59, No. 1, pp. 25-34.

[12] Loomes, Graham, and Robert Sugden, (1982). Regret Theory: An Alternative Theory of Rational Choice under Uncertainty. The Economic Journal 92 (368): 805-24. Doi: 10.2307/2232669. Economic Review 59: 25-34.

[13] S.K. Fuller and S.R. Petersen, (1996). Life-Cycle Costing Manual for the Federal Energy Management Program, NIST Handbook 135, National Institute of Standards and Technology, Gaithersburg, MD.

[14] L.G. Anderson and R.E. Settle, (1977). Benefit-Cost Analysis: A Practical Guide, Lexington Books, Lexington, MA. 